\title{
Nurse egg feeding and energy balance in embryos of Crepidula dilatata (Gastropoda: Calyptraeidae) during intracapsular development
}

\author{
O. R. Chaparro, K. A. Paschke \\ Instituto de Biologia Marina, Universidad Austral de Chile, Casilla 567, Valdivia, Chile
}

\begin{abstract}
On the basis of growth, nurse egg consumption and respiration rate measurements, an energy balance for encapsulated embryos of Crepidula dilatata Lamarck was established in an estuarine population in Southern Chile. Consumption of nurse egg was highest within the first weeks of life of the shelled embryos. Embryonic growth rate was high in terms of shell length and biomass, compared with literature data for pelagic larvae of related species. The hatching process began when the embryos reached shell lengths between 1100 and $1200 \mu \mathrm{m}$ (extreme values: 1075 and $1600 \mu \mathrm{m}$ ). Oxygen consumption values per individual were very low and, consequently, had little influence on the energy balance. During early development, ingested energy met the energy costs of the embryos. The 'balance point' between ingested and consumed energy occurred at a shell length of $650 \mu \mathrm{m}$. Above this size, energy costs greatly exceeded ingested energy; hence larger embryos use energy acquired and stored during the early first development stages. The efficiency with which stored energy was used exceeded $90 \%$ and the high (values $\left(>90 \%\right.$ ) for net growth efficiency $\left(K_{2}\right)$ demonstrate the channeling of ingested energy almost exclusively towards growth.
\end{abstract}

\section{INTRODUCTION}

In addition to providing direct parental care to the embryos some prosobranch gastropods also look after the capsules. Several functions have been attributed to this strategy of encapsulating the embryos, including protection against predation (Phillips 1969, Spight 1975, Pechenik 1979, Perron 1981a, Perron \& Corpuz 1982), sudden osmotic fluctuations (Pechenik 1982 1983) and water loss (Spight 1977, Pechenik 1978), and increasing the probability that offspring remain in the parental area (Chapman 1965, Gibbs 1968, Rivest 1983). Moreover, a possible nutritional benefit has been pointed out, especially in gastropod capsules which enclose extraembryonic yolk in the form of nurse eggs (e.g. Thorson 1950, Gallardo 1976, 1977a, b. 1979a, Spight 1976a, Rivest 1983, Pechenik et al. 1984). thereby supplying additional nourishment to embryos (Pechenik 1986). It is also possible that the intracapsular fluid may play a role in the nutrition of the embryos, as documented for several gastropod species (Bayne 1968, De Mahieu et al. 1974, Clark \& Jensen 1981).

Pechenik (1986) has pointed out that egg capsules are chemically complex and energetically costly, and that their formation requires highly modified female reproductive anatomy, physiology and behavior. He concluded that the advantage of this reproductive mechanism is increased embryonic survival, until now barely understood, which must be very high if it to compensate for the high costs associated with this strategy. Gallardo (1980) considered direct development to be an advanced reproductive mechanism from the energetic point of view, especially in those cases in which development is carried out on the basis of nurse eggs. He proposed that in muricid gastropods the presence of extraembryonic yolk would favour fast embryonic development, reducing the period necessary for the hatching of juveniles, and therefore reducing exposure to mortality pressures in intertidal areas (Gallardo 1979b). Energetic considerations require that large eggs develop more slowly than small ones (McLaren et al. 1969, Steele \& Steele 1973, Wear 1974, Spight 1975 , Perron 1981a), so that basing intracapsular development on the presence of small embryonic eggs together with nurse eggs would apparently be the most efficient means of attaining hatching size more quickly. The short development time reduces problems such as predation and physical stress (Spight 1975). 
In his review, Pechenik (1986) indicated that an experimental approach is necessary to understand the adaptive benefits of encapsulated development and the evolutionary forces responsible for this mechanism. Experiments are particularly required in order to understand the bioenergetic processes in the microenvironment represented by the egg capsule, and its relationship with the success of development, noted by Gallardo (1980). Many questions arise. Is the energy supplied by nurse eggs enough to meet the energy demands of the embryos? Does the intracapsular fluid represent a significant source of nutrition? What are the energetic costs of intracapsular development (measured as respiration)? These questions form the basis of the present investigation into the bioenergetics of the embryos within the egg capsules of the species Crepidula dilatata Lamarck, in which the reproductive biology includes benthic spawning, the provision of nurse eggs and direct intracapsular development.

\section{MATERIALS AND METHODS}

Stones bearing Crepidula dilatata were collected during fall and winter from the subtidal zone in the Quempillén estuary, Ancud, Chiloé, Chile $141^{\circ} 52^{\prime} \mathrm{S}$; $73^{\circ} 46^{\prime} \mathrm{W}$ ). In the laboratory, individuals with capsules adhering to the substrate and containing nurse eggs and/or embryos were detached from the stones for use in the present study.

Nurse eggs and embryo variables. Eggs from several clutches of capsules were washed in $3 \%$ ammonium formate (Thompson 1984), dried for $24 \mathrm{~h}$ at $90^{\circ} \mathrm{C}$ and then weighed. Subsequently, they were combusted at $500^{\circ} \mathrm{C}$ for $15 \mathrm{~min}$ to determine inorganic matter (Toro \& Winter 1983). The weight of the organic fraction was obtained by difference between the dry weight of the eggs before and after ignition. The same procedure was used for embryos of different sizes, to relate organic and inorganic content to shell length.

To measure caloric value, eggs and embryos were obtained separately from several groups of capsules. These were washed and dried as described, and later combusted in a Phillipson oxygen microbomb calorimeter

Growth rate. To establish growth rate (GR: $\mu$ m shell growth $h^{-1} ; \mu g$ organic matter $\left.h^{-1}\right)$, egg masses of Crepidula dilatata were kept without parental care in aquaria with filtered seawater (changed every $3 \mathrm{~d}$ ), at $17 \pm 0.5^{\circ} \mathrm{C}$ and salinity $27 \pm 2 \%$ (close approximations to ambient). Every 2 to $7 \mathrm{~d}, 1$ to 3 capsules were sampled from each spawning mass and the number of eggs and embryos noted as well as maximum embryonic shell length. Since it was not possible to differentiate among embryos and nurse eggs, measurements of growth were carried out from the stage when a velum appeared (shell $>200 \mu \mathrm{m}$ ) until the embryos were close to hatching $(1075 \mu \mathrm{m})$.

Increase in shell length was converted into organic matter using the formula $\mathrm{OM}=3.616 \times 10^{-11} \mathrm{~L}^{2.06}$ (see Fig. 2). The organic matter of the embryos $(\mathrm{GR}=\mu \mathrm{g}$ organic matter $\mathrm{h}^{-1}$ ) was converted into energy units using average caloric values determined for the embryos and expressed in energy/ash free dry weight $\left(\mathrm{GR}=\mathrm{mJ} \mathrm{h}^{-1}\right)$.

Respiration rate. The respiration rate (RR) was quantified by placing capsules in a continuously recording microrespirometer, with a $10 \mathrm{ml}$ volume chamber and constant stirring to homogenize the water in the chamber. The salinity of the seawater used was $27 \pm 2 \%$ with a temperature of $17 \pm 0.5^{\circ} \mathrm{C}$. In each measurement the capsules of a complete spawning were used ( 15 to 24 capsules, 150 to 360 embryos), coming from a single mother, in order to utilize individuals with similar stages of development (same age). RR was measured starting with the egg stage (recent spawning), and continuing up to the maximum prehatching size (1600 $\mu \mathrm{m}$ length). Owing to the difficulty in differentiating clearly between nurse eggs and embryos, oxygen consumption was measured in undifferentiated spawning masses and the lowest values were assumed to be from the most recent spawning, containing only nurse eggs. Total oxygen consumption was then divided by the total egg number in the clutch in order to estimate the consumption of one nurse egg. This value, assumed to be constant throughout the experiment, was used to calculate the oxygen consumption that must be subtracted from the total in order to obtain an estimate for the embryos only.

To calculate oxygen consumption, the total volumes of seawater and intracapsular fluid were considered, assuming the same oxygen saturation for both media. To establish the volume of intracapsular fluid, egg and embryo volumes were calculated, from the most similar geometric figure, and subtracted from capsule volume. Experiments were stopped before the oxygen tension reached a minimum value of $60 \%$ of saturation.

The values of $\mathrm{RR}\left(\mathrm{ml} \mathrm{O} \mathrm{O}_{2} \mathrm{~h}^{-1}\right)$ were transformed to caloric units, using the conversion factor $1 \mathrm{ml} \mathrm{O} 2=19.9$ Joule $=4.75 \mathrm{cal}$ (Thompson \& Bayne 1974).

Ingestion rate. The ingestion rate (IR) of embryos was defined as the number of nurse eggs consumed per hour. For this reason, the ratio between the number of nurse eggs and embryos was established in every capsule, before the embryos started feeding, and at intervals during intracapsular development. The decrease in nurse egg numbers was assumed to be entirely attributable to ingestion by the embryos, and it was also assumed that the ingestion rates were equal for ail embryos. The time period between measured sizes of 
embryos, together with the growth rate, allowed the calculation of IR. The values for the numbers of eggs consumed were transformed into energy units using the caloric estimates ( $\mathrm{R}=\mathrm{mJ} \mathrm{h}^{-1}$ ).

Assimilation rate. Assimilation rate (AR) was calculated following Pechenik's (1980) criterion:

$$
A R=G R+R R .
$$

Assimilation efficiency. Assimilation efficiency (AE), which represents the part of the ingested food that is effectively assimilated, was calculated as:

$$
\mathrm{AE}=\frac{\mathrm{RR}+\mathrm{GR}}{\mathrm{IR}} \times 100
$$

Growth efficiencies. Gross growth efficiency $K_{1}$ (GGE), which provides an estimate of the proportion of the ingested food which is converted into growth (Sprung 1984c), is given by:

$$
\mathrm{GGE}=\frac{\mathrm{GR}}{\mathrm{IR}} \times 100 .
$$

Net growth efficiency $\mathrm{K}_{2}$ (NGE), which defines that part of the assimilated ration which is converted into growth (Sprung 1984c), is calculated thus:

$$
\mathrm{NGE}=\frac{\mathrm{GR}}{\mathrm{GR}+\mathrm{RR}} \times 100 .
$$

\section{RESULTS}

\section{Variables of nurse eggs and embryos}

Total dry weight (W), together with the weights of organic (OM) and inorganic (IM) matter of nurse eggs, are shown in Table 1 . The same variables for shelled embryos are shown in Figs. 1, 2 and 3 and are described by the following equations:

$$
\begin{aligned}
W & =8.465 \times 10^{-11} \mathrm{~L}^{1.99} \\
\mathrm{OM} & =3.616 \times 10^{-11} \mathrm{~L}^{2.06} \\
\mathrm{IM} & =6.673 \times 10^{-11} \mathrm{~L}^{1.85}
\end{aligned}
$$

( $W$ in $g ; O M$ in $g ; ~ L$ in $\mu \mathrm{m}$ ). These variables show a power increase in relation to embryo size.

Table 1. Crepidula dilatata. Mean values for dry, organic and inorganic weight and organic and inorganic matter percentages in nurse eggs. $\pm: \mathrm{SD}_{i}($ ): range

\begin{tabular}{|ccccc|}
\hline $\begin{array}{c}\text { Dry wt. } \\
(\mu \mathrm{g})\end{array}$ & $\begin{array}{c}\text { Organic } \\
\text { matter } \\
(\mu \mathrm{g})\end{array}$ & $\begin{array}{c}\text { Inorganic } \\
\text { matter } \\
(\mu \mathrm{g})\end{array}$ & $\begin{array}{c}\text { Organic } \\
\text { matter } \\
(\%)\end{array}$ & $\begin{array}{c}\text { Inorganic } \\
\text { matter } \\
(\%)\end{array}$ \\
\hline $\begin{array}{c}3.2218 \\
\pm 0.304\end{array}$ & $\begin{array}{r}2.908 \\
\pm 0.251\end{array}$ & $\begin{array}{c}0.3135 \\
\pm 0.077\end{array}$ & $\begin{array}{c}90.34 \\
(87.9-92.7)\end{array}$ & $\begin{array}{c}9.66 \\
(7.3-12.1)\end{array}$ \\
\hline
\end{tabular}

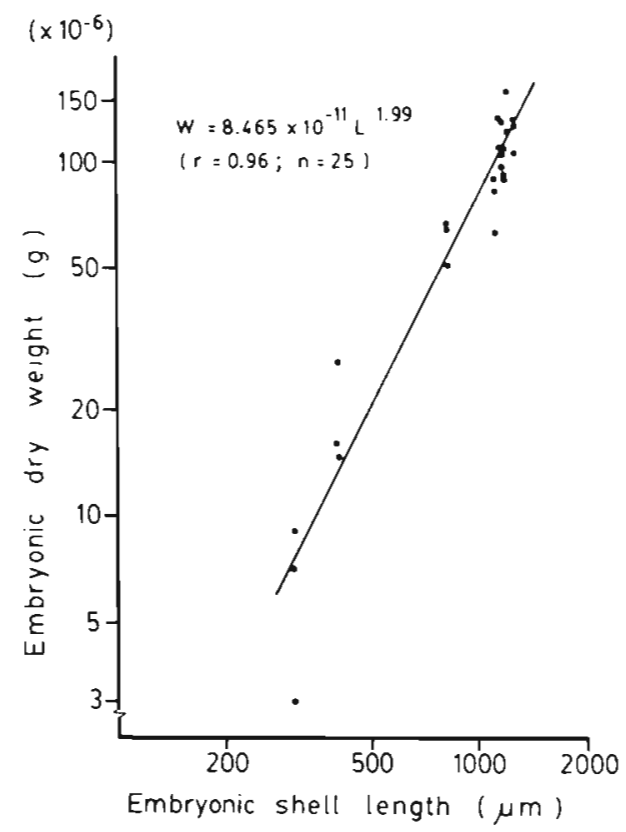

Fig. 1. Crepidula dilatata. Relation between embryonic shell length and embryonic dry weight

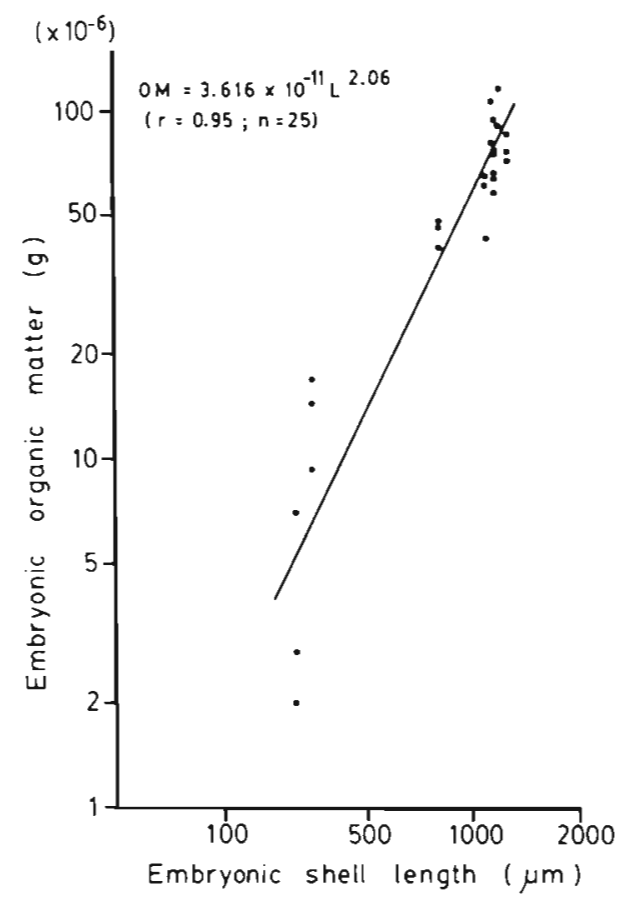

Fig. 2. Crepidula dilatata. Relation between embryonic shell length and embryonic organic matter

The caloric contents of eggs and embryos are shown in Table 2 . In both cases, caloric values are presented in relation to dry weight and ash free dry weight. The eggs had a higher caloric value than the embryos, which contain more inorganic matter. 


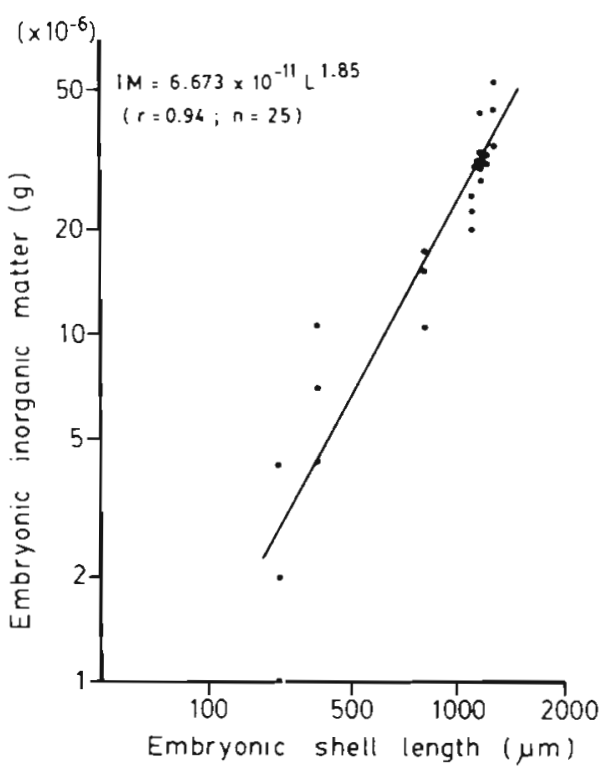

Fig. 3. Crepidula dilatata. Relation between embryonic shell length and embryonic inorganic matter

Table 2. Crepidula dilatata. Mean caloric values $\left(\mathrm{Jg}^{-1}\right)$ of eggs and embryos obtained from subtidal spawning collected in Quempillen river estuary. Embryos $500 \mu \mathrm{m}$ in length. \pm . SD

\begin{tabular}{lcc|}
\hline Stage & Dry wt. & Ash free dry wt \\
\hline Eggs & $23.628 \pm 0.796$ & $23.687 \pm 1.252$ \\
Embryos & $17.393 \pm 0.236$ & $19.368 \pm 0.754$ \\
\hline
\end{tabular}

\section{Growth rate}

There was a linear relationship between developmental time (in days) and the increase in shell length ( $\mathrm{L}$ $=209.29+49.7 D_{i} \mathrm{r}=0.97 ; \mathrm{n}=54$ ) (Fig. 4), but $\mathrm{a}$ power relationship between developmental time and the dry weight of the embryo (Figs. 1, 2 and 3).

The minimum length of hatching recorded was $1075 \mu \mathrm{m}$ and the maximum was $1600 \mu \mathrm{m}$. Most embryos emerged from the capsule at 1100 to $1200 \mu \mathrm{m}$ shell length. According to these data (Fig. 4), 18 to $26 \mathrm{~d}$ are required at $17 \pm 0.5^{\circ} \mathrm{C}$ to reach hatching from the initial stage (embryos with velum and first indications of shell formation).

\section{Respiration rate}

The oxygen consumption ( $\mathrm{RR}=\mathrm{ml} \mathrm{O}_{2} \mathrm{~h}^{-1}$ ) of a single nurse egg was calculated as $1.23 \times 10^{-9} \mathrm{ml} \mathrm{O}_{2} \mathrm{~h}^{-1}$. In the case of embryos, individual oxygen consumption as a function of shell length is represented by the equation

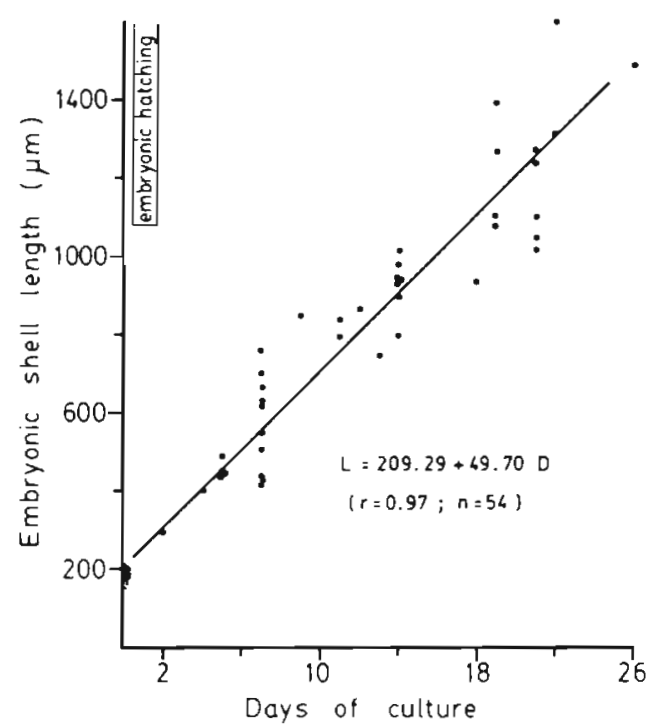

Fig. 4. Crepidula dilatata. Shell length increase in relation to time in culture of encapsulated embryos. Hatching size is shown

$\mathrm{RR}=9.2069 \times 10^{-10} \mathrm{~L}^{074}$ (Fig. 5). The RR values are shown in Table 3 , and are calculated in $\mathrm{ml} \mathrm{O}_{2} \mathrm{~h}^{-1}$ and $\mathrm{mJ} \mathrm{h} \mathrm{h}^{-1}$.

\section{Ingestion rate}

The availability of nurse eggs per embryo was a decreasing exponential function of embryo length (Fig. 6), and is given by: $E E=108.09+(-14.8 \ln \mathrm{L})$. On the basis of this equation, the egg consumption per unit time was established and is summarized in Table 3 , according to the weight and length of the embryo. The amount of food ingested daily is expressed as a percen-

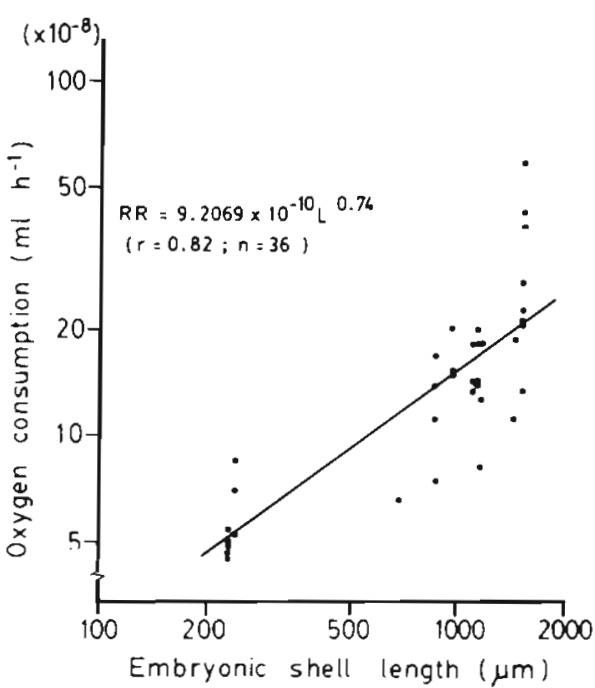

Fig. 5. Crepidula dilatata. Respiration rate in relation to length of encapsulated embryos 
Table 3. Crepidula dilatata. Energy ingested as eggs and its use in various processes by intracapsular embryos $\left(17 \pm 0.5^{\circ} \mathrm{C} ;\right.$ $27 \pm 2 \%$. OM: organic matter; DW - dry weight. \%: ingestion as percentage of embryo dry weight

\begin{tabular}{|c|c|c|c|c|c|c|c|c|c|}
\hline \multicolumn{2}{|c|}{ Embryos } & \multicolumn{2}{|c|}{ Growth rate } & \multicolumn{2}{|c|}{ Respiration rate } & \multicolumn{3}{|c|}{ Ingestion rate } & \multirow{2}{*}{$\begin{array}{c}\text { Ass. rate } \\
\mathrm{mJ} \mathrm{h} \mathrm{h}^{-1}\end{array}$} \\
\hline $\begin{array}{l}\text { Size } \\
(\mu \mathrm{m})\end{array}$ & $\begin{array}{l}\text { DW } \\
(\mu g)\end{array}$ & 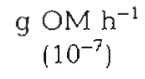 & $\mathrm{mJ} \mathrm{h}^{-1}$ & $\begin{array}{c}\mathrm{ml} \mathrm{O}_{2} \mathrm{~h}^{-1} \\
\left(10^{-8}\right)\end{array}$ & $\begin{array}{c}\mathrm{mJ} \mathrm{h}^{-1} \\
\left(10^{-3}\right)\end{array}$ & Eggs $h^{-1}$ & $\mathrm{~mJ} \mathrm{~h} \mathrm{~h}^{-1}$ & $\% \mathrm{~d}^{-1}$ & \\
\hline 356 & 10 & 0.750 & 1.453 & 7.12 & 1.42 & 0.092 & 7.004 & 71.1 & 1.453 \\
\hline 505 & 20 & 1.112 & 2.154 & 9.21 & 1.83 & 0.062 & 4.720 & 24.0 & 2.155 \\
\hline 619 & 30 & 1.389 & 2.690 & 10.72 & 2.13 & 0.050 & 3.807 & 12.9 & 2.691 \\
\hline 716 & 40 & 1.627 & 3.151 & 11.93 & 2.37 & 0.043 & 3.274 & 8.3 & 3.152 \\
\hline 801 & 50 & 1.824 & 3.533 & 12.96 & 2.58 & 0.039 & 2.969 & 6.0 & 3.534 \\
\hline 878 & 60 & 2.012 & 3.897 & 13.88 & 2.76 & 0.035 & 2.665 & 4.5 & 3.898 \\
\hline 949 & 70 & 2.188 & 4.237 & 14.70 & 2.92 & 0.032 & 2.436 & 3.5 & 4.238 \\
\hline 1015 & 80 & 2.338 & 4.528 & 15.45 & 3.07 & 0.031 & 2.360 & 3.0 & 4.530 \\
\hline 1077 & 90 & 2.522 & 4.884 & 16.14 & 3.21 & 0.029 & 2.208 & 2.5 & 4.886 \\
\hline 1135 & 100 & 2.635 & 5.103 & 16.79 & 3.34 & 0.027 & 2.056 & 2.1 & 5.105 \\
\hline 1191 & 110 & 2.774 & 5.372 & 17.39 & 3.46 & 0.026 & 1.979 & 1.8 & 5.374 \\
\hline 1245 & 120 & 2.933 & 5.680 & 17.96 & 3.57 & 0.025 & 1.903 & 1.6 & 5.682 \\
\hline
\end{tabular}

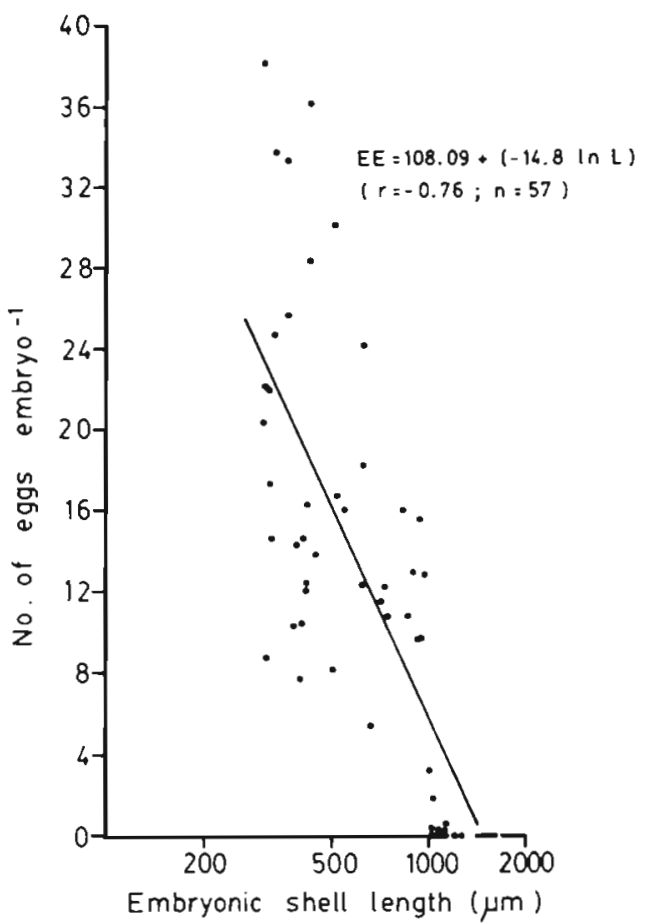

Fig. 6. Crepidula dilatata. Eggs available per embryo in relation to embryo size. From these data ingestion rate per embryo was calculated

tage of the embryo's body weight in Fig. 7. Ingestion rates were very high for small embryos during the early stages of development, but decreased with increasing body size, almost reaching zero in individuals close to $1000 \mu \mathrm{m}$ in shell length (Fig. 6, Table 3).

\section{Assimilation rate}

Assimilation rate increased as the embryo increased in body size (Table 3 ). When egg consumption is ex-

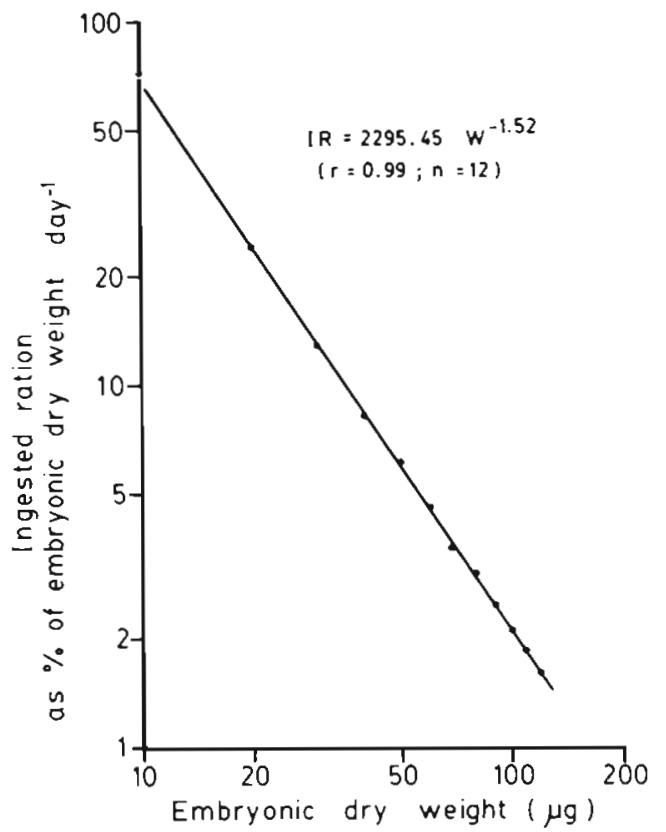

Fig. 7. Crepidula dilatata. Relation between ingested ration $\mathrm{d}^{-1}$ (expressed as percentage of dry weight) and body embryonic size (dry tissue weight) during intracapsular embryonic development

pressed as percentage of embryo body weight, this, however, resulted in a high ingestion rate of nurse eggs during early development of the embryo, and, in a considerable reduction in egg consumption as the embryo grew.

\section{Efficiencies}

Gross and net growth assimilation efficiencies are shown in Table 4 . In all cases, total efficiencies exceed $90 \%$, implying high utilization of energy supplied by nurse eggs. 
Table 4. Crepidula dilatata. Total assimilation efficiency, general gross growth and general net growth efficiencies calculated for intracapsular embryos

\begin{tabular}{|ll|}
\hline Efficiency & $\%$ \\
\hline Total assimilation & 90.35 \\
Total gross growth & 90.28 \\
Total net growth & 99.9 \\
\hline
\end{tabular}

\section{DISCUSSION}

In culture, encapsulated embryos of Crepidula dilatata presented a linear shell growth curve. Hatching from the capsule began when the embryo was $1075 \mu \mathrm{m}$ in length, the size reached after 17 to $18 \mathrm{~d}$ at $17+0.5^{\circ} \mathrm{C}$, taken from the time at which the embryos develop a velum and show the first indications of shell formation. Maximum lengths recorded were ca $1600 \mu \mathrm{m}$, reached after $26 \mathrm{~d}$ of development at $17 \pm 0.5^{\circ} \mathrm{C}$. These values differ from those recorded by Gallardo (1979a) for the same species, who found a maximum length at hatching ranging from 900 to $1300 \mu \mathrm{m}$, although he added that in some populations of the channels in the South of Chile, the maximum can reach 1600 um'. Thus the length of the embryo at hatching varies between populations, perhaps reflecting selective pressures affecting optimal hatching size (Spight 1976b). The mechanisms through which the size at hatching varies in this species may be related to the numbers of eggs and embryos per capsule, since it is closely related to the number of nurse eggs consumed by each embryo (Thorson 1950, Fioroni 1966 , Spight 1976a, Gallardo 1979b, Rivest 1983).

The dry weight and organic/inorganic content of embryos increased exponentially with shell length. The increase in organic matter is greater than that in inorganic matter, which is consistent with the observations of Holland \& Spencer (1973), who found that inorganic shell weight decreases proportionally with total dry weight during larval development in oyster Ostrea edulis. The small increase in inorganic matter results from the formation of the shell, which would not necessarily be highly calcified at this stage. For example, in the gastropod Searlesia dira, shell calcification is incomplete at hatching (Rivest 1983) and further calcification occurs once the embryo emerges from the capsule. On the other hand, the high increase in organic matter in Crepidula dilatata is explained by the 3-dimensional growth of the embryo.

The caloric value of Crepidula dilatata embryos was $19.368 \mathrm{~J} \mathrm{mg}^{-1}$ organic matter, and of eggs $23.687 \mathrm{~J}$ $\mathrm{mg}^{-1}$ organic matter, lower values than those reported for C. fornicata by Pandian (1969) (eggs $=6.209 \mathrm{cal}$ $\mathrm{mg}^{-1}$ organic matter; veliger $=5.298 \mathrm{cal} \mathrm{mg}^{-1}$ organic matter). Veligers of $C$. fornicata store yolk in their own tissue and not in the form of nurse eggs as in $C$. dilatata, which accounts for the caloric differences between the 2 species.

Respiration rate increased as a power function of embryo length, in agreement with data for other molluscan larvae (Pechenik 1980, Gerdes 1983b, Sprung 1984b), but the values for Crepidula dilatata were lower than those recorded for planktonic bivalve larvae, especially when expressed in terms of biomass (Sprung 1984b). It is clear that the swimming of planktonic larvae (Sprung 1984a) as well as their filtering activity results in higher energetic costs. Neither of these considerations applies to $C$. dilatata embryos, since their movements within the capsule are minimal, and food (nurse eggs) is readily available within the capsule, close to the embryo. The low oxygen consumption can also be a consequence of the potential barrier represented by the internal capsule walls that confine the embryos (Strathmann \& Chaffee 1984, Wolf et al. 1985), since in some cases (e.g. gelatinous egg masses of the opisthobranch Melanochlamys diomedea), long diffusion patterns result in reduced rates of gas exchange and excretion of waste products, leading to asynchrony in the development of the embryos (Chaffee \& Strathmann 1984).

Nurse eggs represent a source of food for the embryos in Crepidula dilatata, as in other species of molluscs (Spight 1976a, Gallardo 1977b, 1979b, 1980 , 1981, Pechenik 1984). Furthermore, some authors have pointed out the possibility that 'abortive embryos' may be used as food for embryos (Coe 1949, Hendler \& Franz 1971, Gallardo 1976, 1981, Rivest 1983). This may also occur in C. dilatata, since abortive embryos were observed in the early development stages, but never in the final stages.

Considering only nurse eggs as a food source for embryos, ingestion can be calculated on the basis of the decrease in egg number in relation to time or embryos length. The relation between the number of eggs and embryos was variable among capsules, even within the same spawning (Gallardo 1976, 1977a, 1979a). The number of available nurse eggs per embryo during early development ranged from 8 to 38 (Fig. 6) in the population of $C$. dilatata studied here, whereas Gallardo (1977a, 1979a) observed, in 2 other populations, a range of from 16 to 18 and 12 to 22 eggs per embryo respectively.

Ingestion rate showed a logarithmic relation with embryo length. Most of this ingestion occurred during the early embryonic stages, decreasing as the embryo increased in size. According to this feeding behaviour, and from the high initial consumption by embryos about $300 \mu \mathrm{m}$ in length, it appears that a high pro- 
portion of the organic material consumed is utilized during the subsequent stages of embryonic development. A high initial rate of consumption has also been described for other gastropods, such as Searlesia dira (Rivest 1983) and Nucella crassilabrum (Gallardo 1979b), and is possibly attributable to movements of the early embryo within the capsule, perhaps to move close to the nurse eggs. This capability would be lost once the embryos increase in body size, completely filling the interior of the capsule.

Low consumption of nurse eggs was observed in embryos up to $1000 \mu \mathrm{m}$ in length, above which the embryos began to hatch, although in some cases the embryos continued growing within the capsule to lengths approaching $1600 \mu \mathrm{m}$. The final stages of growth are not dependent on egg consumption, since the availability of nurse eggs is normally zero or very low when the embryo has reached $1000 \mu \mathrm{m}$ in length, but on the egg 'reserves' that the embryo has built up during early development. Dissolved organic material may also be involved in embryonic growth, as indicated by Bayne (1968), De Mahieu et al. (1974) and Clark \& Jensen (1981).

The ingested ration, expressed as a percentage of the embryo dry weight, is high during the early stages of development, reaching a maximum of $70 \% \mathrm{~d}^{-1}$, and falling almost to zero when the embryo approaches the hatching size (Fig. 7). Such high ingestion percentages have been reported for molluscan larvae as well as for juveniles and adults (e.g. Winter 1978, Gallardo 1979b, Gerdes 1983a, Rivest 1983, Winter et al. 1984, Navarro 1988).

The energy invested in growth, which represents the main component of the energy equation, showed a large increase as the embryo increased in size. The balance point between energy ingested in the form of nurse eggs and energy invested in growth is reached in embryos of ca $650 \mu \mathrm{m}$ shell length. In larger embryos energy used for growth surpasses ingested energy (Fig. 8). The resulting energy deficit is probably supplied by egg material stored in the stomach during previous embryonic development stages, and by other energy sources such as dissolved organic material present within the capsule or the internal capsule wall (De Mahieu et al. 1974).

Further confirmation for the use by advanced embryos of energy deposited by earlier ingestion of nurse eggs is provided by the data in Fig. 9, which shows that the curves relating stored energy and energy invested in growth to shell length are well separated for small embryos, indicating that ingestion exceeds metabolic costs, but when the embryos approach the hatching period the curves converge, even though ingested energy slightly exceeds the energy used in embryonic metabolism. The energy

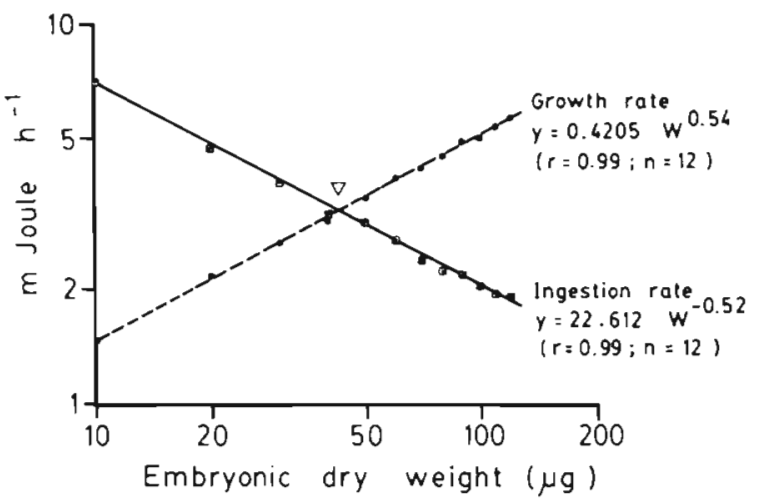

Fig. 8 Crepidula dilatata. Ingestion and growth rate (expressed as energy) in relation to embryo dry weight during intracapsular development. $(\nabla)$ Equilibrium between ingested energy and energy used in the growth process

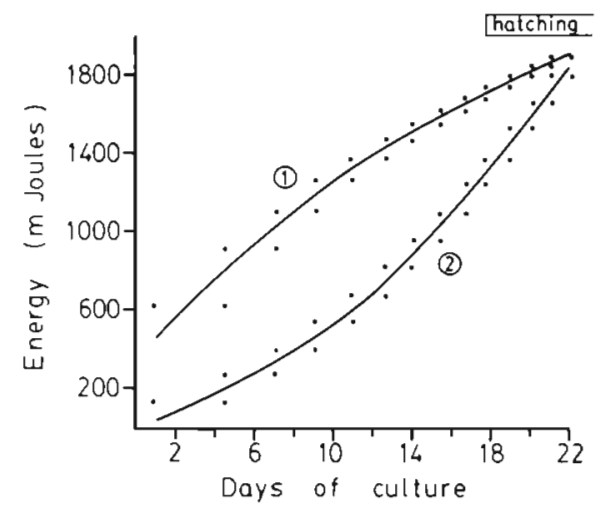

Fig. 9. Crepidula dilatata. Ingestion (1) and growth (2) rate (both accumulated and expressed in energy units) during intracapsular development

balance is therefore positive, with an accumulated assimilation efficiency of $90.35 \%$ and $K_{2}$ values close to $100 \%$. Such high efficiencies indicate that practically all the assimilated energy is invested in growth. Pandian (1969) reported lower values $(61 \%)$ for Crepidula fornicata, when the balance is expressed in terms of energy.

According to these energy balance calculations, and assuming that the intracapsular fluid may have some nutritive value (Bayne 1968, De Mahieu et al. 1974), the role of this fluid as an energy source in this species is not likely to be significant (Pechenik et al. 1984). Nevertheless, it may play other important roles in the development of the embryo, such as providing an environment that (i) facilitates oxygen diffusion within the capsule (Strathmann \& Chaffee 1984) and (ii) gives protection (Perron 1981a) by enabling flotation of the embryo (Rivest 1983).

The encapsulation strategy in Crepidula dilatata appears to be efficient in providing energy to the developing embryos. The high growth rate of the embryos is attributable to this mode of nutrition by nurse eggs, and to the fact that practically all the 
Table 5. Literature data (obtained or calculated) on daily growth rates ( $G R=\mu m \mathrm{~d}^{-1}$ ) of larvae of some prosobranch gastropods

\begin{tabular}{llccc|}
\hline Species & $\begin{array}{c}\text { GR } \\
\left(\mu \mathrm{m} \mathrm{d}^{-1}\right)\end{array}$ & $\begin{array}{c}\text { Size } \\
\text { range }(\mu \mathrm{m})\end{array}$ & $\begin{array}{c}\text { Culture } \\
\text { temperature }\left({ }^{\circ} \mathrm{C}\right)\end{array}$ & Source \\
\hline Crepidula plana & 30 & $300-786$ & 18.5 & Ament $(1979)$ \\
C. fornicata & 18.3 & $200-920$ & 18.5 & Ament $(1979)$ \\
C. fornicata & 25 & $339-639$ & 20 & Lucas \& Costlow $(1979)$ \\
C. fornicata & 24.3 & $481-1160$ & $19-20$ & Pechenik $(1980)$ \\
Ilyanasa obsoleta & 20.3 & $300-786$ & $19-20$ & Pechenik (1980) \\
C. fornicata & 45.3 & $350-900$ & 1.8 & Pechenik (1984) \\
C. plana & 28 & $323-941$ & 20 & Lima \& Pechenik (1985) \\
C. plana & 44.2 & $300-1300$ & 17 & Lima \& Pechenik (1985) \\
C. dilatata & 50 & & & This study \\
\hline
\end{tabular}

energy ingested is converted into biomass. At the same time, the low energetic costs of respiration must be stressed, since mobilization in search of food is not needed.

The low energetic costs of Crepidula dilatata embryos, combined with the high assimilation efficiency, result in high growth rates that greatly exceed those planktonic larvae characteristic of other prosobranch gastropods when developed at $20^{\circ} \mathrm{C}$ or less (Table 5). However, Perron (1981b) reported higher growth rates for some larvae of the genus Conus, although developing at higher temperatures $\left(24\right.$ to $\left.26^{\circ} \mathrm{C}\right)$. Finally, the accumulation of biochemical energy reserves enables the embryo, once hatched at a length of 1100 to $1200 \mu \mathrm{m}$, to search for an appropriate site without any urgent need to feed or to form an appropriate structure for post-hatching feeding. The existence of these reserves of energy is evident in those embryos which continue their intracapsular growth up to $1600 \mu \mathrm{m}$, since the consumption of nurse eggs is normally restricted to embryos smaller than $1000 \mu \mathrm{m}$ in length. It is clear that intracapsular embryonic development, such as described here in $C$. dilatata, provides evolutionary advantages as proposed by Gallardo (1980)

Acknowledgements. The authors thank Drs. C. Bertran, J. Cancino, C. Gallardo, J. Navarro and R. Thompson for helpful comments on an earlier version of this manuscript. We are grateful to the Quempillen Station (Ancud-Chiloé) and its staff for providing Crepidula material. This work was supported by Grant A/846 of the International Foundation for ScienceSweden, FONDECYT-Chile (5056/86), Dirección de Investigación-Universidad Austral de Chile and the International Development Research Center-Canada.

\section{LITERATURE CITED}

Ament, A. S. (1979). Geographic variation in relation to life history in three species of the marine gastropod genus Crepidula: growth rates of newly hatched larvae and juveniles. In: Stancyk, S. E. (ed.) Reproductive ecology of marine invertebrates. Univ of South Carolina Press, p. $61-76$
Bayne, C. J. (1968). Histochemical studies on the egg capsules of eight gastropod molluscs. Proc. malac. Soc. Lond. 38: $199-212$

Clark, K. B., Jensen, K. R. (1981). A comparison of egg size, capsule size, and development patterns in the order Ascoglossa (Sacoglossa) (Mollusca: Opistobranchia). Int. J. Invertebrate Reprod. 3: 57-64

Chaffee, C., Strathmann, R. R. (1984). Constraints on egg masses. I. Retarded development within thick egg masses. J. exp. mar. Biol. Ecol. 84: 73-83

Coe, W. R. (1949). Divergent methods of development in morphologically similar species of prosobranch gastropods. J. Morphol. 84: 383-400

Chapmann, G. (1965). The egg cocoons of Scoloplos armiger Müller. Biol. Bull. mar biol. Lab., Woods Hole 128 189-197

De Mahieu, G. C., Penchaszadeh, P. E., Casal, A. B. (1974) Algunos aspectos de las variaciones de proteinas y aminoacidos libres totales del líquido intracapsular en relación al desarrollo embrionario en Adelomelon brasiliana (Lamarck, 1811) (Gastropoda, Prosobranchia, Volutidae). Cah. Biol. mar. 15: 215-277

Fioroni. P. (1966). Zur Morphologie und Embryogenese des Darmtraktes und der transitorischen Organe bei Prosobránchiern (Mollusca: Gastropoda). Rev. suisse Zool. 73 $621-876$

Gallardo, C. S. (1976). Historia natural y reproducción de Crepidula dilatata Lamarck en una población de Bahia Mehuin (Prov. Valdivia, Chile). Medio ambiente 2 (1): $44-50$

Gallardo, C. S. (1977a). Two modes of development in the morphospecies Crepidula dilatata (Gastropoda: Calyptraeidae) from Southern Chile. Mar Bıl. 39: 241-251

Gallardo, C. (1977b). Crepidula philippiana n. sp., nuevo gastropodo Calyptraeidae de Chile con especial referencia al patrón de desarrollo. Stud. Neotrop. Fauna Environ. 12: $177-185$

Gallardo, C. S. (1979a). Especies gemelas del genero Crepidula (Gastropoda, Calyptraeidae) en la costa de Chile; una redescripción de $C$. dilatata Lamarck y descripción de C. fecunda n. sp. Stud. Neotrop. Fauna Environ. 14: 215-226

Gallardo, C. S. (1979b). Developmental pattern and adaptations for reproduction in Nucella crassilabrun and other muricacean gastropods. Biol. Bull. Mar. biol. Lab., Woods Hole 157: 453-463

Gallardo, C. S. (1980). Adaptaciones reproductivas en gas- 
trópodos muricáceos de Chile: conocimiento actual y perspectivas. Inv. mar. Valparaíso 8 (1-2): 115-128

Gallardo, G. S. (1981). Posturas y estadio de eclosión del gastrópodo muricidae Chorus giganteus (Lesson, 1829) Stud. Neotrop. Fauna 16: 35-44

Gerdes, D. (1983a). The Pacific oyster Crassosostrea gigas. Part I. Feeding behavior of larvae and adults. Aquaculture 31: 195-219

Gerdes, D. (1983b). The Pacific oyster Crassostrea gigas. Part II. Oxygen consumption of larvae and adults. Aquaculture 31: $221-231$

Gibbs, P. E. (1968). Observations on the population of Scoloplos armiger at Whitstable. J. mar Biol. Ass. U.K. 48: 225-254

Hendler, G., Franz, D. R. (1971). Population dynamic and life story of Crepidula convexa (Gastropoda, Prosobranchia) in Delaware Bay. Biol. Bull. mar. Biol. Lab., Woods Hole 141: $514-526$

Holland, D. L., Spencer, B. E. (1973). Biochemical changes in fed and starved oyster, Ostrea edulis L. during larval development, metamorphosis and early spat growth. J. mar Biol. Ass. U.K. 53: 287-298

Lima, G. M., Pechenik, J. A. (1985). The influence of temperature on growth rate and length of larval life of the gastropod, Crepidula plana Say. J. exp. mar. Biol. Ecol. 90: 55-71

Lucas, J. S., Costlow, J. D. Jr (1979). Effects of various temperature cycles on the larval development of the gastropod mollusc Crepidula fornicata. Mar Biol. 51: 111-117

McLaren, I. A., Corkett, C. J., Zillioux, E. J. (1969). Temperature adaptations of copepod eggs from the arctic to tropics. Biol. Bull. mar. Biol. Lab., Woods Hole 137: 486-493

Navarro, J. M. (1988). The effects of salinity on the physiological ecology of Choromytilus chorus (Molina, 1782) (Bivalvia, Mytilidae). J. exp. mar Biol. Ecol. 122: 19-33

Pandian, T J. (1969). Yolk utilization in the gastropod Crepidula fornicata. Mar. Biol. 3: 117-121

Pechenik, J. A. (1978). Adaptation to intertidal development: studies on Nassarius obsoletus. Biol. Bull. mar Biol. Lab. Woods Hole 154: 499-506

Pechenik, J. A. (1979). Role of encapsulation in invertebrate life histories. Am. Nat. 114: 859-870

Pechenik, J. A. (1980). Growth and energy balance during the larval lives of three prosobranch gastropods. J. exp. mar Biol. Ecol. 44: 1-28

Pechenik, J. A. (1982). Ability of some gastropod egg capsules to protect against low-salinity stress. J. exp mar. Biol. Ecol 63: 195-208

Pechenik, J. A. (1983). Egg capsules of Nucella lapillus (L.) protect against low-salinity stress. J. exp. mar. Biol. Ecol. 71: $165-179$

Pechenik, J. A. (1984). The relationship between temperature, growth rate, and duration of planktonic life for larvae of gastropod Crepidula fornicata (L.). J. exp. mar Biol. Ecol. 74: $241-257$

Pechenik, J. A. (1986). The encapsulation of eggs and embryos by molluscs: an overview. Am. malac. Bull. 4 (2): 165-172

Pechenik, J. A., Chang, S. C., Lord, A. (1984). Encapsulated development of the marine prosobranch gastropod Nucella lapillus. Mar. Biol. 78: 223-229

Perron, F. E. (1981a). The partitioning of reproductive energy between ova and protective capsules in marine gastropods of the genus Conus. Am. Nat. 118: 110-118

Perron, F. E. (1981b). Larval biology of six species of the genus Conus (Gastropoda: Taxoglossa) in Hawaii, U.S.A. Mar Biol. 61: 215-220

This article was presented by Dr J. E. Winter, Valdivia, Chile
Perron, F. E., Corpuz, G. C. (1982). Costs of parental care in the gastropod Conus pennaceus: age-specific changes and physical constraints. Oecologia (Ber1.) 55: 319-324

Phillips, B. F. (1969). The population ecology of the whelk Dicathias aegrota in western Australia. Aust. J. mar. Freshwat. Res. 20: 225-265

Rivest, B. R. (1983). Development and the influence of nurse egg allotment on hatching size in Searlesia dira (Reeve, 1846) (Prosobranchia: Buccinidae). J. exp. mar Biol. Ecol. 69: $217-241$

Spight, T M. (1975). Factors extending gastropod embryonic development and their selective cost. Oecologia (Berl.) 21 $1-16$

Spight, T M. (1976a). Hatching size and the distribution of nurse eggs among prosobranch embryos. Biol. Bull. mar. biol. Lab., Woods Hole 150: 491-499

Spight, T. M. (1976b). Ecology of hatching size for marine snails. Oecologia (Berl.) 24: 283-294

Spight, T. M. (1977). Do intertidal snail spawn in the right places? Evolution 31: 682-691

Sprung, M. (1984a). Physiological energetics of mussel larvae (Mytilus edulis). I. Shell growth and biomass. Mar. Ecol. Prog. Ser. 17: 283-293

Sprung, M. (1984b). Physiological energetics of mussel larvae (Mytilus edulis). III. Respiration. Mar. Ecol, Prog. Ser. 18: $171-178$

Sprung, M. (1984c). Physiological energetics of mussel larvae (Mytilus edulis). IV Efficiencies. Mar Ecol. Prog. Ser. 18: $179-186$

Steele, D. H., Steele, V. J. (1973). The biology of Gammarus (Crustacea, Amphipoda) in the north-western Atlantic. VII. The duration of embryonic development in five species at various temperatures. Can. J. Zool. 51: 995-999

Strathmann, R. R., Chaffee, C. (1984). Constraints on egg masses. II. Effect of spacing, size, and number of egg on ventilation of masses of embryos in jelly, adherent groups, or thin-walled capsules. J. exp. mar Biol. Ecol. 84: 85-93

Thompson, R. J. (1984). Partitioning of energy between growth and reproduction in three populations of the sea urchin Strongylocentrotus droebachiensis. Adv. Invertebrate Reprod. 3: 425-432

Thompson, R. J., Bayne, B. L. (1974). Some relationships between growth, metabolism and food in the mussel Mytilus edulis. Mar. Biol. 27: 317-326

Thorson, G. (1950). Reproductive and larval ecology of marine bottom invertebrates. Biol. Rev. 25: 1-45

Toro, J. E., Winter, J. E. (1983). Estudios en la ostricultura Quempillén, un estuario del Sur de Chile. Parte I. La determinación de los factores abióticos y la cuantificación del seston como oferta alimenticia y su utilización por Ostrea chilensis. Mems Asoc. Latinoam. Acuicult. 5 (2): 129-144

Wear, R. G. (1974). Incubation in British decapod Crustacea, and the effects of temperature on the rate and success of embryonic development. J. mar. Biol. Ass. U.K. 54: 745-762

Winter, J. E. (1978). A critical review on some aspects of filterfeeding in lamellibranchiate bivalves. Haliotis 7: 71-87

Winter, J. E., Acevedo, M. A., Navarro, J. M. (1984). Quempillen estuary, an experimental oyster cultivation station in southern Chile. Energy balance in Ostrea chilensis. Mar. Ecol. Prog. Ser. 20: 151-164

Wolf, G., Verheyen, E., Vlaeminck, A., Lemaire, J., Decleir. (1985). Respiration of Sepia officinalis during embryonic and early juvenile life. Mar Biol. 90: 35-39

Manuscript first received: January 10, 1990

Revised version accepted: April 30, 1990 